doi: $10.19090 / \mathrm{i} .2020 .31 .183-196$

UDC: $341.24 " 1914 / 1917$ "

\author{
MIROSLAV RADIVOJEVIĆ \\ University of Belgrade, Faculty of Philosophy \\ Department of History \\ miroslav.radivojevic@f.bg.ac.rs
}

\title{
SERBIA, ITALY'S ENTRANCE INTO WORLD WAR I, AND THE LONDON AGREEMENT: A NEW INTERPRETATION*
}

\begin{abstract}
This paper follows the Entente Powers negotiations with Italy from the beginning of World War I up to the signing of the London Agreement. Simultaneously, this paper follows Serbian relations towards the negotiations and Italy entering the conflict from the standpoint of its national pretensions. Due to the important role of Russia, as Serbia's closest ally and the traditional protector of Slavic interests, special attention has been dedicated to its position and reasons for relenting in diplomatic initiative for Italy entering the war. This paper contains an analysis and a new interpretation of the London Agreement. In addition to this, the paper sheds light on the beginning of deteriorating relations between the governments in Rome and Belgrade/Niš, which used to be friendly before the Great War, as well as the circumstances which influenced the situation.

Keywords: London Agreement, Serbia, Italy, Russia, World War I, Nikola Pašić, Sergey Sazonov, Sir Edward Grey, the Yugoslav issue, Dalmatia.
\end{abstract}

$\mathrm{S}$ hortly before World War I, Serbia and Italy maintained mostly good relations. In the initiatives comprising Serbian interests, Italy was more inclined towards Russia and the Entente Powers than it was toward Austria-Hungary (and Germany). This was apparent especially when Italy supported the project of constructing the Adriatic railway and the Serbian port in Albania, and during negotiations concerning Eastern railway ownership. Right before and during the July Crisis, the Italians had a benevolent attitude towards Serbia. They kept the Triple Entente states and the government in Belgrade informed about Austria-Hungary's and Germany's intentions. ${ }^{1}$ A change in Italy's position occurred during the Great War. The Yugoslav program of the Serbian government collided with Italian pretensions on the Adriatic east coast. Mutual conflict became inevitable.

\footnotetext{
This article is a part of the project "Srpska nacija - integrativni i dezintegrativni procesi" ("Serbian nation Integrative and Disintegrating Processes”) № 177014 supported by the Ministry of Education, Science and Technological Development of the Republic of Serbia.

1 Aleksić-Pejković 1965: 760-775, 782-784; Id 1987: 255-270; May 1952, 364-365; Radivojević 2019: 7577, 85, 122, 126; Ćorović 1992: 553-558, 704-706.
} 
Italy declared neutrality at the beginning of the conflict, referring both to the not having been informed about the Dual Monarchy's and Germany's intentions in a timely manner, and the spirit of the mutual agreement - the fact that the war was not defensive. Taking into consideration it was a Great Power, both groups of the conflicted parties were motivated to win it over. Russia was the first of the Triple Entente to enter the negotiations. Encouraged by the Italian ambassador in Saint Petersburg, Russian Minister of Foreign Affairs, Sergey Sazonov, wanted to make the most of the initial advantage - Italy's territorial pretensions were primarily directed at Austro-Hungarian land. Early on, in the first half of August, in return for entering the war, he promised them Trentino, Trieste, and Vlorë, together with the dominant position at the Adriatic coast, under one condition - that Serbia also got free access to the coast, in a proportion that would be agreed on afterwards. Despite being in accordance with Serbian interests, Sazonov's step was precipitant and was not fully supported by French and British diplomacy. ${ }^{2}$ Making a specific offer seemed premature to the allies from the Entente, and they advised more precaution. ${ }^{3}$

Sazonov's initiative was encouraged by mid-August when both France and Great Britain formally declared war on Austria-Hungary. However, Rome was not ready for a serious step forward. Still being a member of the Triple Alliance, Italy did not want to do "what could be called a larcenous strike against Austria". ${ }^{4}$ Nevertheless, in front of the Entente's diplomatic representatives, Italian officials did not rule out entering the war as an option if circumstances changed in the future. Among other things, the Italians asked for the negotiations to be moved to London, away from the Austro-Hungarian and German diplomats. ${ }^{5}$ Officials in Saint Petersburg anticipated the Italian goal, upon them suggesting the place for negotiations - to take everything they could conquer by armed force. ${ }^{6}$ On August 24, Russian Foreign Minister warned the allies to avoid premature promises about the coast of Dalmatia, which was "almost exclusively populated by Serbs".?

The tide of battle and the Triple Entente's victories in September indeed aroused Italy's interest for a potential compensation scope. Along with the conversations held in other allies' capitals, the Italian representative in Niš was interested in Serbia's pretensions toward the Adriatic coast. Despite a cordial reception, the host officials did not show their

2 It is interesting that Russian Foreign Minister used the possibility of Italy entering the war to pressure Serbia to hurry with the offense against the enemy, in order to forestall Rome's requests "most of which could be in discrepancy with Serbian interests". He sent a similar note to the Greek Government, as they hesitated to enter the conflict, MOEI, VI-1, document number 70-71.

3 AS, MID PO, 1914, roll 430, Fascicle XIV, dossier 7, 420; BD, XI, № 148, 365, 502, 543, 579, 668-669; DSPKS, VII-2, № 579, 590, 685, 763; MOEI, V, № 60-61, 95, 131, 407, 414-415, 453, 459-460, 488, 494, 521, 529, 542, 556; VI-1, № 24-25, 35, 42, 54, 63-64, 74, 77, 79-80, 86, 95; VI-2, № 622; PSR I, № 146-147; Ekmečić 1973: 282-285, 290-292; Janković 1973: 102-103; Marjanović 1960: 22-33; Šepić: 1970: 1-4.

4 MOEI, VI-1, no 91.

5 In case of Italy entering the war, the Entente Powers guaranteed their demands for French and British fleet cooperation at the Adriatic Sea as early as in the preliminary talks, and confirmed they would not make a separate peace without Italy’s consent, MOEI, VI-1, № 104, 161.

6 AJ, 80-I-5, 251-253; AS, MID PO, 1914, r. 425, F. XI, d. 1, 82; r. 430, F. XIV, d. 7, 423; MOEI, VI-1, № 87, 91, 104, 109, 113, 117, 123, 161, 164, 168-169, 183, 186, 192, 194, 197, 200; PSR I, № 247-248, 297, 699; Tsarskaya Rossiya I: 236-248; Živojinović 1973: 308-315; Marjanović 1960: 33-38; Petrovich 1963: $162-$ 170; Popović 1977: 182-188; Šepić 1970: 3-5.

7 MOEI, VI-1, № 117, 154. 
cards. From the beginning of the war, Serbian Prime Minister Nikola Pašić was careful not to violate Italian interests through military actions by Serbian and Montenegrin armed forces in Albania or Dalmatia. ${ }^{8}$ Having received confirmation about Italian inquiries from the diplomatic representatives as well, by the end of September he warned the Entente members about the possibility that the local population would resist occupation. Additionally, he asked the Russian Government to prevent "speculation" and the Italian wish "to benefit from shed Slavic blood" and also not to allow intruding "Slavic countries" further than Trentino, Trieste, and half of Istria with Pula". Such backbone turned out to be right. They maintained the previous firm stance on the Pevcheskiy Bridge ${ }^{10}$ and repeated their warning to London and Paris about the perspective that Italy's requests were not to violate Serbian interests. ${ }^{11}$

When the danger of the Serbian army's total defeat in the Battle of Kolubara provoked a worried statement from Italy, it occurred to Sazonov to reply that the crisis would be resolved by Italy entering the war, as this would make Austria-Hungary withdraw a part of their forces from the Balkans. The Russian foreign minister missed no opportunity to warn the government in Rome that their aspirations would not be taken into consideration during the future peace congress without Italy entering the war. Having spoken with the British ambassador, he also protested against rumors about an Italian initiative for an alliance among Bulgaria, Romania, and Greece. Creating a new bloc of the Balkan countries with no room for Serbia, was impermissible for Russia; however, including Serbia would remove all these obstacles. ${ }^{12}$ Another confirmation of Sazonov's stance was an interview he gave to Corriere della serra toward the end of the year, when he once more advocated against Italian "pretensions toward Dalmatia, an area which was completely inhabited by Serbs and had been a constituent of Serbia prior to the Turkish invasion". ${ }^{13}$

During the first few months of war, both Serbia and Italy made efforts to avoid dispute. Thus the representative of Serbia said to one of the host officials in Rome that "the Italian army would be welcomed as liberating, the day they went to defy Austria-Hungary

8 On the contrary, Russia hoped for the action of Serbia, Montenegro or the allies' fleet at the Adriatic Coast. According to them, Dubrovnik or Kotor occupation should have provoked Italy entering the conflict, taking into consideration its pretensions and fears that this area's destiny would be irretrievably solved this way without its participation, MOEI, VI-1, № 283, 333; Radivojević 2019: 158.

9 AJ, 80-II-9, 42ob; II-10, 186 и ob; VII-40, 450-451; AS, MID PO, 1914, r. 430, F. XIV, d. 7, 434ob-435; MOEI, VI-1, № 351-352.

10 In accordance with the tradition of the time, Great Powers were named after the address, the building or the landmark where Foreign Ministry was located, thus there were two phrases for Russia in the diplomatic language - the Pevcheskiy Bridge or the Court Square.

11 AJ, 80-I-5, 253-254; II-9, 40-42; II-11, 459-462; AS, MID PO, 1914, r. 430, F. XIV, d. 7, 427-428ob, 432434ob; VA, P. 3, K. 77, F. I, 1/17; MOEI, VI-1, № 18, 36, 248, 257, 310, 313, 332, 357, 361, 368, 386, 390, 397, 410, 413, 430, 440; VI-2, 497; PSR I, № 297, 307, 345, 354, 398; Ekmečić 1973: 285-286, 292-294; Živojinović 1973: 315-317; Janković 1973: 103-106; Marjanović 1960: 34, 44-48, 51-52; Petrovich 1963: 171-174; Popović 1977: 188-190; Šepić 1970: 6-18.

12 AJ, 80-XI-52, 474-476, 484 i ob, 488 i ob, 491 i ob; AS, MID PO, 1914, r. 442, F. XXV, d. 7, 229-233, 236 238ob; Tsarskaya Rossiya I: 254; MOEI, VI-2, № 461, 482, 514, 524, 553, 585, 590, 629, 638, 651, 661, 758; VII-1, 11; PSR I, № 537, 664-665, 721.

13 Popović 1977: 191. 
across Serbian and Croatian land". ${ }^{14}$ The news about the great turn in the Battle of Kolubara was received with enthusiasm by the Italian public. "They got their fingers burned," declared King Victor Emmanuel at the time, referring to the Austrians. ${ }^{15}$ It seemed that the mutual conflict would be cleared up. In reality, that did not happen. What irritated Italy was Serbian and Croatian emigration from Austria-Hungary, as they were propagating the Slavic character of Dalmatia under the auspices of the government in Niš. Italian occupation of Vlorë further influenced the deterioration of relations. Fear appeared in Niš that the operations would spread along the Albania coast. One must take into consideration that the other party was not willing to overcome disagreements either. Despite their earlier consent, Rome confronted the Serbian desire to occupy certain points in Albania in order to watch their back. Of course, this was only the prologue of dissension. ${ }^{16}$

The role of the Great Powers and the attention that both blocs of the countries in war paid to the negotiations with Italy greatly influenced its position. Rome followed developing events, waiting for the right moment to monetize its position. Expectedly, Austria-Hungary kept refusing to make significant territorial concessions, which increasingly directed the views from Consulta towards the opponents. Apart from being of great importance for potentially changing relations of the forces in the Mediterranean, beginning of the Entente military operation in the Dardanelles in February 1915 was the turning point for Italy's orientation change. The Italian ambassador very soon appeared in front of the British Foreign Secretary, Sir Edward Grey. He handed in the written form of the conditions for entering the war on behalf of his country on 9 March $1915 .{ }^{17}$ The unanticipated step took place only a few days after Sazonov's statement that he perceived Italy entering the war "not without qualms" at the moment when "its cooperation both at sea and on land greatly lost value" - which could only "justify its great territorial enlargement." The Russian minister feared that the entrance of a fourth country could lead both to the deterioration of the true and honest relations among the Entente Powers and difficulties in the future peace negotiations. ${ }^{18}$ Allied pressure, motivated by the perspective of speeding up the conflict end and importance of the Dardanelles operation, forced him to concede. He also got additional stimulus from Great Britain and France - their consent to Russian possession of

\footnotetext{
PSR I, № 537.

Ibid. № 744, 810 .

AJ, 80-I-5, 256-259ob; II-10, 190 и оb, 194, 196-197; II-11, 466-469; VIII-41, 4-5, 13, 39, 41; XI-52, 492 і ob; AS, MID PO, 1914, r. 427, F. XII, d. 1, 30-32ob, 36; r. 430, F. XIV, d. 7, 432-434ob, 490-491ob, 495; MID SPA, 1914, № 515, 654, 785, 804, 811, 817, 863, 874, 911, 917, 951; 1915, 977; ASANU, 9864/9; DARSM, 17.2.7-8/11-14; PSR I, бp. 374, 477, 490, 783; II, 1; Tsarskaya Rossiya I: 252-253; MOEI, VI-1, № 219, 281, 355, 386, 404, 413, 438; VI-2, 561, 572, 590, 633, 648, 695, 703, 730, 735, 737-738, 742, 755, 758; VII-1, 1, 23, 80, 127, 203, 354, 368; Arsh 2002: 129-133; Ekmečić 1973: 294-295, 302-320, 335-369; Marjanović 1960: 34-35, 52-55, 61-63, 93-125, 140-152; Petrovich 1963: 174-178; Popović 1977: 192195; Šepić 1967: 1-55; Id. 1970: 19-54.

17 The territories Serbia was interested in, included in the Memoire were: Vlorë with the surroundings, Trieste, whole Istria up to the Kvarner, Dalmatia up to the Neretva River, the Pelješac peninsula and all the islands north and west of it. It was left for Europe to decide upon the end of the conflict what would be the solution for the area between the Volosko port and the north line of Dalmatia, and between the Neretva and the Drim. MOEI, VII-1, № 276, 281.
} 
Constantinople and the Straits upon the end of the war. ${ }^{19}$

Russia did not question most of the Italian requests, apart from those referring to the Adriatic basin. In the Memoire to Tsar Nikolay II from 15 March, after consultations in the headquarters of Commander in Chief - Stavka, Sazonov accepted Trieste, Istria, and the Kvarner islands cession. He advocated for the area between Volosko (a small settlement, northeast of Opatija) and the border of the area he meant to give to Montenegro ("somewhere slightly north of Dubrovnik") to be given to Serbia and Croatia, regardless of the latter political form upon the armed conflict end. In case a new conversation relenting was necessary "on the fly", he defined "the widest possible protection of the Serbian monarchy's interests" as Russia's main goal. Final concessions for Italy were to include the land between Volosko and the mouth of the Krka River, initially meant for the Croats. They were not allowed to sacrifice anything further than Šibenik in the Serbian zone on the left bank of the Krka. ${ }^{20}$

Grand Duke Nikolay Nikolayevich Romanov had an important influence on the foreign minister's initial attitude change and his consent to negotiate with Italy. The chief commander of the Russian armed forces found no alternative for the deciding offense in the foreseeable future, but for the cooperation with Italian or Romanian army. France and Great Britain had an identical viewpoint regarding the "first-rate role" of Italy. With predominance in the battlefield, drawing Italy closer was expected to induce negotiations with the neutral Balkan countries. Russians confronting the possibility that Italy would take over AustrianHungarian role, would block the access to the coast for Serbia and Montenegro and would sow the seeds of discord in the future, weakened faced with the warfare needs. ${ }^{21}$ For the sake of pressuring Russian diplomacy, Paris and London kept employing their consent to the possession of Constantinople and the Straits. In return, they expected Sazonov neither to tighten nor to slow down the negotiations flow, not even regarding the timeframe within which Italy was supposed to take action. ${ }^{22}$

By the end of March, information about secret conversations in London reached Niš. Delegates of Yugoslav emigration from Austria-Hungary, together with the diplomatic channel sources, kept Pašić informed about "the extraordinary difficult situation regarding

19 AS, MID PO, 1914, r. 427, F. XII, d. 2, 113; 1915, r. 442, F. I, d. 1, 6; r. 447, F. III, d. 6, 1006; MOEI, VI-1, № 219, 290; VI-1, 621; VII-1, 47, 203, 205, 274-275, 303, 306, 318, 322, 328, 331, 341-343, 349, 351-355; PSR I, № 451, 460, 721, 759; II, 2, 17, 21, 33, 135, 194; Tsarskaya Rossiya I: 258-259, 261, 264; Vinogradov 2002; 156-157; Živojinović 1971: 62-68; Marjanović 1960: 27-29, 38-40, 113-116, 133-140, 162-172; Petrovich 1963: 178-182; Popović 1977: 196-197; Salvemini 1925: 553-561; Stanković 1984: 131-132.

20 Russia opposed the Adriatic area neutralization, as they were meant for the Slavic countries; especially for the coast of Montenegro, MOEI, VII-1, № 373, 378; Tsarskaya Rossiya I: 262-264; Marjanović 1960: 172-174.

21 At the end of March Foreign Office expressed fear that Italy could possibly accept Germany's offer for maintaining neutral position. Grey pressured Russia to agree with Rome's requests. "He suspected Serbia would complain about insufficient Entente support", as in perspective it should obtain tripled territory and wide access to the sea "for trade development". The chance to "shorten the war by many months" should not have been missed, "only" for the sake of securing "limited coast space”, MOEI, VII-2, № 451 .

22 MOEI, VII-1, № 203, 378, 381, 388-389, 393-394, 396, 399, 402, 408, 414; VII-2, 417-420, 423, 426, 430, 439$441,444,448,450-453,455-456,461-463,465,471,474-475,477,479,485-487,489-494,511,535,537$, 539, 545-546, 550, 558, 563-564, 566-568; PSR II, бp. 157, 214, 217, 219, 234, 237; Tsarskaya Rossiya I: 264 267, 272-278, 281-285; Byukenen 1991: 147-148; Janković 1973: 111-112; Marjanović 1960: 174-181, $185-$ 209, 211-223; Petrovich 1963: 182-191; Popović 1977: 197-199, 202-208; Šepić 1967: 56-62; Id. 1970: 54-60. 
the north half of the Adriatic coast" ${ }^{\prime 23}$. Right at the time, a Croatian politician from Dalmatia, Frano Supilo, was in Saint Petersburg asking for an energetic objection from Serbia. His request was responded to. Crown Prince Regent Aleksandar and Prime Minister Pašić expressed their expectation to Russian Minister in Nish Grigoriy Trubetskoy, that would defend Slavic nations' interests on the Adriatic coast at the Pevcheskiy Bridge. The response was prompt. On 3 April Sazonov replied that Russia would not sign the agreement "without securing a wide access to the seaside for Serbia" - and added a few days later - "the country which sacrificed the most and did the greatest favors". ${ }^{24}$ The Serbian Government did not stop there. On 6 April Pašić sent a circular to the diplomatic representatives abroad, in which he asked the Triple Entente for "the Yugoslav provinces not to become transaction objects" during the London negotiations "causing damage to Serbs, Croats and Slovenes, Europe and European peace". ${ }^{25}$ The initiative gained momentum through Serbian action in the allies' public. Under the influence of amplified polemics of Italian and Russian press, Serbian Prime Minister and Minister of Foreign Affairs made a note once more towards the end of April. However, Sazonov, who had previously been made to calm down the press tone, kept reminding that he was not in charge of everything. ${ }^{26}$

Russian Foreign Minister fiercely protested the manner Sir Grey defended British and French interests, especially in regard to the colonies in Africa and Asia Minor, whereas he showed an "extraordinary will" for cession in areas where Russia was interested in "decreasing Italian desires", so he "did not even hide" who presented an obstacle for the agreement from the Italian ambassador in London. Already resigned, he protested saying that his positions were not being taken enough into consideration. "Had I expected such negotiations conducting from Grey, I would never have consented to them being held in British capital," the imperial Minister regretted. ${ }^{27}$ However, finally, "under the allies' pressure" 28 and not without protest, he accepted most of the Italian requests. Faced with dilemma between territorial minimum necessary "for independent existence" of Serbia on one side and the needs of Croats and Slovenes on the other, he made concessions to the damage of the latter. Sazonov mostly succeeded in fulfilling the mentioned program of "the widest possible protection" of Serbian countries' interests from his Memoire to Tsar on $15 \mathrm{March}^{29}$

According to the London Agreement on 26 April 1915, among other areas, Italy got a part of Dalmatia up to the Planka Cape (not far from Sibenik to the southeast), without the Pelješac peninsula they had asked for, but with almost all the islands. "The interest sphere" of Serbia and Montenegro spread between the Planka Cape and the River Drim confluence and included the rest of the islands (Drvenik Veliki, Drvenik Mali, Čiovo, Koločep, Jakljan,

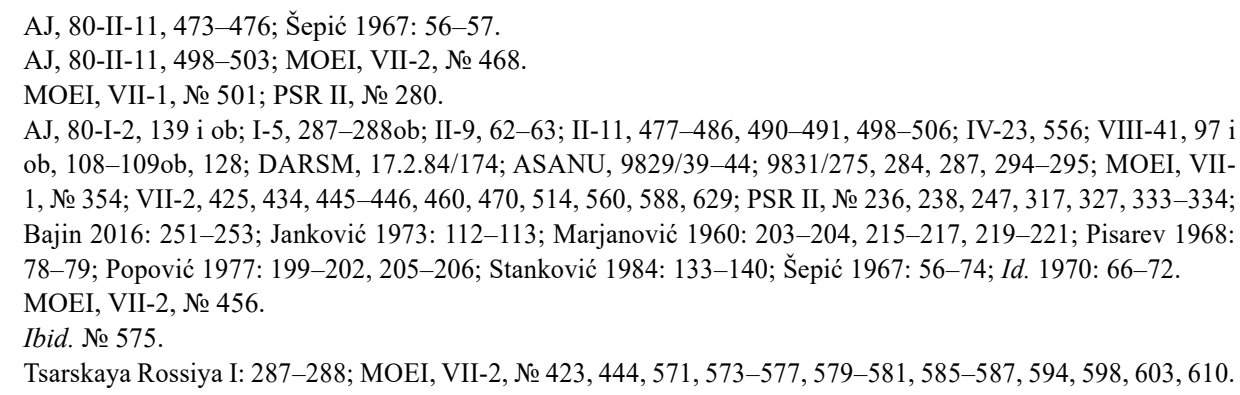


Šolta and Brač). After "a long fight" resembling "the one between the Trojans and the Achaeans over Achilles' body", ${ }^{30}$ Russia succeeded both in avoiding the whole coast neutralization and in potentially enabling Serbia complete freedom of movement from the lower edge of Pelješac up to ten km south of Cavtat for military purposes. The part of the coast already possessed by Montenegro was meant to have the same treatment. ${ }^{31}$ Additionally, there was a perspective of joining Shkodër, Shëngjin, and Lezhë to Montenegro. Italy was to take Vlorë with the surrounding area; the central part of Albania with Durrës would form a small autonomous country, while Serbia and Greece were meant to have a mutual border, "spacious enough" west of Ohrid lake. Finally, Croatia would get the coast from Volosko to the north point of Dalmatia. ${ }^{32}$

At the time of signing, Russia's position that the London Agreement fulfilled the minimum of the small ally's interests, was the opposite of the Serbian political elite views. ${ }^{33}$ Along with securing Serbia strategically, the Pašić's work of was based on the principle of a "fair solution to the Adriatic issue" in the spirit of the "three-named nation" unity. ${ }^{34}$ The Russian foreign minister would try to explain in vain that it would be "impossible to achieve the whole ideal at once," taking into consideration that Italy entering the war was of "great interest". ${ }^{35}$ The Serbian prime minister had already sent prominent scientists to the Entente Powers capitals, with the aim of keeping the officials and the public informed about the Yugoslav issue. Professors Ljubomir Stojanović and Aleksandar Belić were supposed to go to Saint Petersburg. As the news about signing an agreement with Italy, with the help of significant relenting on the Russian side had arrived, Pašić again decided to go to the city on the Neva River himself. The reply did not differ much from the one received a month earlier, after Regent Aleksandar's suggestion. The Serbian prime minister's visit was

30 Salvemini 1925: 561.

31 Due to the compromise about Šibenik, Sazonov changed his mind about the possible borderline between the Serbian states, compared to the projection in the Memoire to Tsar. According to the new one, Dubrovnik and Cavtat were to be owned by Serbia.

32 Agreement 1920: 3-4; MOEI, VII-2, № 537, 612-617, 619, 623, 633, 644, 646, 658; Tsarskaya Rossiya I: 293; Marjanović 1960: 445-449; Petrovich 1963: 191-193. Yugoslav historiography has remained scarce about the London Agreement. On the Croatian side there was a tendency to perceive the territory meant for Serbia and Montenegro as mutual, or simply not to analyze it in detail. This tendency was so strong to the extent that they used the second-rate sources in interpretation; contemporaries' memories, instead of using available document - agreement between the Allies and Italy. However, Serbian historians complete the reprehensible image with a certain dose of contradiction, by denying previous statements from the sources about the negotiations flow and by avoiding to confront the problematic topics. In that sense, there is a generalization of the territorial solutions in the Agreement as "violation of Serbia's war goals" or "Yugoslav interests", Janković 1973: 115; Marjanović 1960: 232-241; Popović 1977: 206-208; Stanković 1984: 132133; Šepić 1970: 71-73.

33 Despite the fact that the Agreement had a secret tone, the Entente practically revealed territorial division of the lower Adriatic coast in the memoire sent to the Serbian Government on 15 August 1915, with the aim of its relenting the negotiations with Bulgaria, Radivojević 2019: 182.

34 AJ, 80-I-2, 139 и оb; Stanković 1984: 137-139; Šepić 1970: 77-78.

35 Although he himself considered Italian aspirations exaggerated, he advised patience. "In the next ten or fifteen years you will fight again, and then you will accomplish even what you could not accomplish now; your army will do wonders then as it is doing now", said Sazonov. He believed "it would be easier for Serbia to deal with them, than it was with Austria-Hungary, since neither the Italians were good soldiers at all, nor was Italy a Great Power", AJ, 80-II-11, 498-503, 549-551. 
described as "useless," as it could not influence the negotiations further flow and conclusion. This would be inconvenient both for himself and for the imperial government. ${ }^{36}$ They kept convincing from the Pevcheskiy Bridge that they were doing "all they possibly could to defend Serbian and Slavic interests". ${ }^{37}$

Rumors about concessions to Italy were stirring up the situation in Niš. Croatian politicians in exile added fuel to the fire, stating that they were preparing people in Dalmatia to repel Italy. ${ }^{38}$ Pašić endured attacks from a few sides. He had already received estimations about the compensation scope from the diplomatic representatives. On 29 April for an instant the Serbian prime minister neglected the Yugoslav program and took an interest in the issue concerning the Serbian people primarily. Speaking with Trubetskoy during the London negotiations, he asked for Russia to take care of possession of Šibenik and the territory surrounding the Krka River, inhabited mostly by an Orthodox population. However, it was only a short reflection. Continuing to protest fiercely against the way compensations were granted behind Serbia's back and without its approval, Pašić returned to the well-known constructions of the "Serbian-Croatian-Slovenian" people and coast. ${ }^{39}$

As May began, the Serbian government was given confirmation about the day the London Agreement had been signed and a rough insight into its content. The situation in other allies' capitals was similar to the one in Saint Petersburg - the representatives were appeased by claims that Serbia's national pretensions were taken into consideration during the negotiations. The French minister of foreign affairs, Théophile Delcassé, considered that "if this war turned out well for the allies, Serbia would profit the most" and that "we should be able to moderate our demands" as "in reality an ideal was hard to reach completely" ${ }^{40}$ It was stated from London that "Russia and the allies take the biggest care of Serbian interests," and added that "compromise was inevitable" and that "we should be satisfied with what we got, in order not to lose everything." At the time, Great Britain made an "official and confidential" promise of joining Bosnia, Herzegovina, and "a wide part of the coast" to Serbia as well as the union with Croats, if they were willing to do so. ${ }^{41}$ Similar friendly notes came from the Italian diplomacy representatives as well. However, none of these fully complied with Serbian expectations. ${ }^{42}$

36 AJ, 80-II-9, 66-67ob; II-10, 218-230; II-11, 573-576; V-27, 240-241; MOEI, VII-2, № 460, 468, 626, 638, 653; PSR II, № 254; Bajin 2016: 253-254; Popović 1977: 208-209; Trgovčević 1986: 40-42; Šepić 1960: 453-457. MOEI, VII-2, № 638.

37 MOEI, VII-2, № 638 .

38 The main reason why Duke Trubetskoy supported the Saint Petersburg visit of Belić and Stojanović, was actually taking away from "the South Slavs" the accusation that Serbia had not done enough for "the action of national union”, MOEI, VII-2, № 570, 595, 605. His superiors found in the same manner that Pašić was given a "shelter" against the opposition and Croatian-Slovenian emigration, as he was left with no option, having been denied the permission to visit Saint Petersburg, Id. 638, 645, 655; AJ, 80-II-11, 583-588; Popović 1977: 208-209.

39 AJ, 80-I-2, 141-144; I-6, 424-428, 432-433ob; II-8, 615-617ob; II-9, 64-65ob, 72-78; II-11, 521-522ob, 540-545, 553-565; IV-24, 602-610; VIII-41, 113 i ob, 122 i ob; MOEI, VII-2, № 588, 626-629, 642, 645, 655, 681, 720; PSR II, № 363-364; Bajin 2016: 254-255; Janković 1973: 115-117; Pisarev 1968: 105-106; Popović 1977: 209-210, 212-213; Šepić 1967: 73-76; Id. 1970: 78-80.

40 PSR II, № 362.

41 Ibid. № 379; MOEI, VII-2, № 686, 698.

42 AJ, 80-I-2, 145-146; I-5, 311; II-10, 244-245; II-11, 566-590, 595-597, 615-616; IV-23, 557-558; AS, MID PO, 1915. r. 447, F. IV, d. 3, 175; VA, K. 67, F. V, 5/14; PSR II, № 363, 389; Stanković 1984: 140-142. 
Serbia opted for one more note to the Entente Powers. In accordance with the decision made at the government session which the regent took part in on 3 May, Pašić made a vigorous protest to the allies' representatives. A few days later, a written note was formed on the basis of the protest. Taking this step, the Prime Minister relied on the general public, political circles, and people's discontent with the rumors about the agreement with Italy - which damaged the national union. In order to relieve the difficult position of the ministerial cabinet, suspected not to have enough foreign support, he asked from Russia, Great Britain, and France: 1) assurance that the territory issue had not been irretrievably solved, and that it would be looked into in a direct agreement with Italy; 2) that they would not determine borders on the other sides without previous agreement with Serbia; 3) a warranty for Serbian-Croatian-Slovenian union; 4) that they would influence Italian armed forces not to hurry with the "most sensitive" areas breakthrough, in order to avoid conflict with the locals. Speaking with the Entente representatives, for the sake of achieving effect, Pašić mentioned possible Government resignation. ${ }^{43}$

Simultaneously with the diplomatic action, Crown Prince Aleksandar sent a letter to Grand Duke Nikolay Nikolayevich. He indicated that "one and a half million of pure-blood Slavs were left to Italy" which meant "a hundred and fifty thousand excellent soldiers," all the ports, strategic points, and merchant exits at the Adriatic coast. He indicated the injustice and danger of the perspective in which Italy could take over the role of Austria-Hungary in the Balkans. Thus, he as the commander of Russian armed forces was warned about the moral repercussions such politics would have on Serbian army and its "difficult mental state". ${ }^{44}$

It is visible that Serbia expected support from a de facto patron - Russia. While the Chief Commander Headquarters refused to meddle in political matters, quite picturesque messages were coming from the Pevcheskiy Bridge. Along with promises, Sazonov sent serious warnings. Not only did he find Serbian reprimands that Russia had taken insufficient care of its interests "unfair," but he also thought they were "indecent" and threatened to produce "the worst impression." Imperial protection of Serbia had led to the war in which Russia was burdened the most; yet the Empire did not cease to help Serbia both in a material and diplomatic manner. He added that it would become visible upon publishing documents about the negotiations with Italy, that he "fought for each foot of the land" regardless of "the most inconvenient circumstances." And Serbia "should better not forget" that it still did not own the demanded areas and regardless of its army qualities, those areas could only be obtained thanks to the allies' (primarily Russia's) battlefield success. "I cannot say that all the wishes of certain exalted Serbian patriots will be granted, but I am sure that you will get a territory so large that you will not be able to put it in order even in a hundred years," Sazonov stated almost prophetically. ${ }^{45}$

He did not understand why Belgrade University Professors Aleksandar Belić and Ljuba Stojanović kept refusing to recognize Italy's right to part of Dalmatia. He asked them "not to resent" his being a Russian firstly, as he was "a Serb right after that" and "the Serbian

43 AJ, 80-IV-24, 611-614ob; ASANU, 14447; 14924/43; MOEI, VII-2, № 690; PSR II, № 388; Janković 1973 : 117-118; Popović 1977: 213-214; Stanković 1984: 142-145; Šepić 1970: 81-82.

44 AJ, 80-IV-24, 604-607; AS, Marambo, F. XLI; MOEI, VII-2, № 607

45 AJ, 80-II-11, 601-602; MOEI, VII-2, № 645, 689; Bajin 2016: 255. 
people's interests were the closest to him." "Serbia's merits will be rewarded hundredfold" he kept convincing them by mentioning Bosnia and Herzegovina, a probable union with Montenegro, and obtaining Dalmatian coast with "old Split". ${ }^{46}$ On 7 May Trubetskoy calmed down the "despondent" prime minister a bit, using his superior's arguments. Pašić accepted to stop with "barren and even damaging" action of stirring the public up. He even reconciled with the fact that the compromises might have been inevitable, but he regretted his not having been informed about them in a timely manner, so that he could have prepared the public in due course. He warned the press in Niš not to express discontent and distrust of the closest ally when writing about Dalmatia and also to spare Italy, until they entered the war. Serbian statesman accepted one more warning from the Russian representative. He convinced Frano Supilo not to return to Saint Petersburg and sent him to Great Britain, since he continued with the propaganda and organized protests in Niš together with the opposition. ${ }^{47}$

Serbian national leaders had way too dramatic viewpoint. ${ }^{48}$ Italy was quite willing to keep friendly relations. The Italian ambassador in Russia stated in mid-March that the "independence and prosperity of Serbia" were "of utter importance" for his country. ${ }^{49}$ A month earlier, Italian diplomacy sent a similar note to Austria-Hungary, warning that any Austrian-Hungarian military action in the Balkans would be considered a breach of the mutual allies' agreement if taken without previous consultation. It is peculiar that King Vittorio Emmanuele simultaneously assured the Serbian prince Đorđe that the Italian pretensions would be very moderate upon the end of war. ${ }^{50}$

Rome tried to remove distrust not very long after initialing the London Agreement. It is possible that Pašić was partly calmed down by the statement of the Italian Minister in Niš, shortly before the aforementioned reception of Trubetskoy. Baron Niccolo Squitti, who had already wired the superiors about the public anxiety provoked by the rumors about the great concessions to Italy, conveyed the Italian message about their intention to "enter into an agreement as soon as this is all over" as they wanted "on no account to be enemies" of Serbia. On the basis of this statement, Pašić counted on "quick action" of the new ally" Russia also supported the initiative and the mutual benefits that both parties would obtain from the agreement, which could possibly be signed by Croatia as well. However, it turned out to be no more than a bluff, intended to calm down the stirred-up situation in Niš. Despite Serbian expectations and preparations for negotiatiions, Italy showed no intention to actually keep their promise. ${ }^{52}$

46 AJ, 80-II-11, 607; Popović 1977: 211, 217.

47 AJ, 80-II-11, 600ob, 615-617; IV-23, 557; AS, MID PO, 1915. r. 447, F. IV, d. 3, 185; r. 448, F. IV, d. 3, $213-$ 214; MOEI, VII-2, № 689, 705, 720; Popović 1977: 212-213, 215-216; Šepić 1960, 458-465: Id. 1967: 77 81; Id. 1970: 82, 100-105.

48 One of the positive things in the whole situation was the fact that Russian, French and British representatives in Niš, following their superiors' instructions, gave statements for joining Bosnia, Herzegovina and "wide area of land" in Dalmatia, that they would "take into consideration Serbian interests" in Banat and they would allow "federal state" with Croats, depending on their willingness, AJ, 80-VIII-41, 147, 156-157; XI-51, 291; AS, MID PO, 1915. r. 447, F. IV, d. 3, 175; MOEI, VII-2, № 686, 689, 698, 705, 720; Šepić 1970: 93-94. MOEI, VII-1, № 354

Ibid. № 203, 389.

AJ, 80-IV-23, 558-559.

AJ, II-11, 623-626, 634-635, 653-658ob, 686-689; AS, MID PO, 1915. r. 447, F, III, d. 5, 846; F. IV, d. 3, 
The mutual relations had significantly deteriorated by the time of the enemy offense in the autumn of 1915. Pašić pressured the Chief Command, insisting on a possible military agreement being dependent on the previous political issues arrangement, and also on a reserved attitude towards the Italian military attaché. On the one hand, the trust decreased by the action of Serbian army, directed towards occupying strategic points in Albania by its inaction in the battlefield with Austria-Hungary and stronger propaganda about the Yugoslav union. On the other hand, mutual connections were being worsened by the suspicion about Italian relations with the Montenegrin king Nikola, by refusing to reveal the text of the London Agreement and refusing to approve of the Serb and Croat union. Sazonov was right when he asked France and Great Britain to limit Italy's influence on negotiations about Serbian concessions to Bulgaria. Official Niš skillfully used "victims" in Dalmatia to tighten negotiations with other neutral countries. ${ }^{53}$

Triple Entente negotiations with Italy showed that "military needs" often outweighed small allies' interests. Luckily, once more Russia was on the side of Serbia, which did not directly take part in the negotiations. Unlike the conversations with other neutral countries, the London Agreement might have protected Serbian pretensions best. As it has been mentioned, Sazonov mostly succeeded in achieving "the broadest Serbian Monarchy interests" from the program Memoire to Tsar on 15 March 1915. Naturally, Russia had its own interests together with the protector role. Italian demands for strategic points and occupation of the islands and the coast neutralization, partly supported by the west Triple Entente members, was based on the fear of Russia constructing military ports which would be used by its fleet. Russian positioning on the Adriatic coast via Serbia and Montenegro, combined with occupying Constantinople and the Straits, would level up its status of the sea force and would mean that their centuries-old dream about access to the "warm seas" would come true.

The Serbian government's Yugoslav program did not influence the London conversations flow. Niš protests had almost no other use but to irritate the Entente Powers' officials. Russia, France, and Great Britain did not understand the need to aim for the maximum in the national program accomplishment, all the while neglecting serious territorial acquisitions. Historical experience showed the core of the mistake Serbia had made - renouncing its own statehood, territorial spread and drowning in "unity." Opting for the unity with Croats and Slovenes significantly deepened the gap with Italy, which was the Great Power, despite everything. The fact that Rome did not see the matters realistically and

183; VRS VIII: 88; MOEI, VIII-1, 145, 188; VIII-2, 659; PSR II, № 389, 399, 505; Stanković 1984: 145-146; Šepić 1970: 82-84.

53 AJ, 80-II-11, 591-593ob, 667-676, 690-693, 699-704, 716-717; IV-21, 327-342; AS, MID PO, 1915, r. 442, F. I, d. 1, 33 и оb; r. 447, F. IV, d. 3, 188; r. 448, F. IV, d. 3, 236-237ob; VA, P. 3, K. 91, F. IV, 19/91; DARSM, 17.2.199/415; MOEI, VII-2, № 729; VIII-1, 29, 39, 95, 101, 108, 116, 145, 153, 160, 188, 221, 244, 278, 280 , 285, 306, 313, 418, 424, 428; VIII-2, 463, 474, 497-498, 522-523, 530-533, 541, 558, 586, 606, 635, 647, 659, 734, 759; PSR II, № 378, 380, 395, 428, 435, 439, 445, 447, 449-450, 505-506, 516, 530, 541-542, 551-552, 559, 563, 567, 570, 593-594, 620, 627, 633, 637, 639, 659; Salvemini 1925: 561-562; Trgovčević 1986: 45-71; Šepić 1967: 79-107; Šepić 1970: 85-146. 
showed lack of interest for the small ally's needs must not be neglected. At the end, Italy entering the war did not justify the enormous territorial concessions, and did not have a decisive role in the war. The London Agreement attainments were mostly rejected at the peace congress. However, the consequences of the Agreement were significant. The vision of its (un)accomplishment had for decades been deteriorating Italy's relations with the former big allies and the Kingdom of Serbs, Croats, and Slovenes, and had finally led to mutual hostility.

\section{REFERENCES:}

Unpublished sources:

Archives of Yugoslavia (Arhiv Jugoslavije - AJ)

Fond 80, Personal Collection of Jovan Jovanović Pižon

Archives of Serbia (Arhiv Srbije - AS)

Ministry of Foreign Affairs

Political Department (MID PO)

Strictly Confidential Archive (MID SPA)

Personal Fond of Vojislav Jovanović Marambo

Archives of the Serbian Academy of Sciences and Arts (Arhiv Srpske akademija nauka i umetnosti ASANU)

9829, 9831, 9864, Legacy of Radoslav Jovanović

14447, Diary of colonel Radivoje Bojović

14924, Legacy and materials of Nikola Pašić

Military Arhives (Vojni arhiv - VA)

Inventory book 3 - Materials of the war archive of the Serbian Supreme Command, 1914-1920.

The State Archives of the Republic of North Macedonia (DARSM)

Fond 17, Ministry of Foreign Affairs of the Kingdom of Serbia

Published sources:

Agreement between France, Russia, Great Britain and Italy, signed at London, April 26, 1915, London: His Majesty's Stationery Office, 1920. (Agreement)

Gooch, G. P. and Temperley, H. with the assistance of Penson, L. M. British documents on the origins of the war 1898-1914. Volume XI. The Outbreak of War, London, His Majesty's Stationery Office, 1926. (BD)

Byukenen, Dz. Memuary diplomata, Moskva: Mezhdunarodnye otnosheniya, 1991. (Russian Cyrillic)

Tsarskaya Rossiya v Mirovoy voyne. Tom I, Leningrad: Gosudarstvennoe Izdatel'stvo, 1923. (Tsarskaya Rossiya) (Russian Cyrillic)

Dedijer, V. and Anić, Ž. Dokumenti o spoljnoj politici Kraljevine Srbije 1903-1914, Tom VII-2, Beograd: 1980. (DSPKS) (Serbian Cyrillic)

Perišić, M. and Marković and A. Škodrić, Lj. and Bogdanović, B. Prvi svetski rat u dokumentima Arhiva Srbije, Tom I, Beograd: Arhiv Srbije, 2015. (PSR I) (Serbian Cyrillic)

Škodrić, Lj. and Marković, A. and Bogdanović, B. Prvi svetski rat u dokumentima Arhiva Srbije, Tom II, Beograd: Arhiv Srbije, 2016. (PSR II) (Serbian Cyrillic)

Mezdunarodnye otnosheniya $v$ epohy imperializma. Dokumenty iz arhivov tsarskogo $i$ vremennogo previtel'stv 1878-1917. Seriya III. Tom V-VIII, Moskva and Leningrad: Gosudarstvennoe social'no-ekonomicheskoe izdatel'stvo, 1934-1935. (MOEI) (Russian Cyrillic) 
Šepić, D. Pisma i memorandumi Frana Supila (1914-1917), Beograd: Naučno delo, 1967. (Serbian Cyrillic)

References:

Aleksić Pejković, Lj. Odnosi Srbije sa Francuskom i Engleskom 1903-1914, Beograd: Istorijski institut, 1965. (Serbian Cyrillic) . „Italija i Jadranska železnica“, Istorijski časopis, 34, 1987, 255-270. (Serbian Cyrillic)

Arsh, G. L. and Vinogradov, V. N. Za balkanskimi frontami Pervoy mirovoy voyny, Moskva: Indrik, 2002. (Russian Cyrillic)

Bajin, Z. Miroslav Spalajković (1869-1951). Biografija (PhD dissertation), Beograd: Filozofski fakultet, 2016. (Serbian Cyrillic)

Ćorović, V. Odnosi između Srbije i Austro-Ugarske u XX veku, Beograd: Biblioteka grada Beograda, 1992. (Serbian Cyrillic)

Ekmečić, M. Ratni ciljevi Srbije 1914, Beograd: Srpska književna zadruga, 1973. (Serbian Cyrillic)

Janković, D. Srbija i jugoslovensko pitanje 1914-1915. godine, Beograd: Institut za savremenu istoriju and NIP Eksport-pres, 1973. (Serbian Cyrillic)

Marjanović, M. Londonski ugovor iz godine 1915. Prilog povijesti borbe za Jadran 1914-1917, Zagreb: Jugoslavenska akademija znanosti i umjetnosti, 1960.

May, A. J. 'Trans-Balkan Railway Schemes', The Journal of Modern History, 24, 4, 1952, 352-367.

Petrovich, M. B. Russian Diplomacy and Eastern Europe, New York: King's Crown Press, 1963.

Pisarev, Y. A. Serbiya i Chernogoriya v Pervoy mirovoy voyne, Moskva: Nauka, 1968. (Russian Cyrillic)

Popović, N. Odnosi Srbije i Rusije u Prvom svetskom ratu, Beograd: Institut za savremenu istoriju and Narodna knjiga, 1977. (Serbian Cyrillic)

Radivojević, M. Srbija i Rusija 1913-1918 (PhD dissertation), Beograd: Filozofski fakulet, 2019. (Serbian Cyrillic)

Stanković, Đ. Đ. Nikola Pašić, saveznici i stvaranje Jugoslavije, Beograd: Nolit, 1984.

Salvemini, G. „Italija u Svetskom ratu“, Nova Evropa, XI, 18, 1925, 553-570.

Šepić, D. Italija, saveznici i jugoslavensko pitanje 1914-1918, Zagreb: Školska knjiga, 1970. . "O misiji Lj. Stojanovića i A. Belića u Petrogradu 1915. godine“, Zbornik Historijskog instituta Jugoslavenske akademije znanosti i umjetnosti, 3, 1960, 449-497.

Živojinović, D. R. „San Đulijano i italijanske pretenzije na Jadranu na početku Svetskog rata“, Istorijski časopis, 20, 1973, 307-317. (Serbian Cyrillic)

Živojinović, D. „Uloga admirala Paola Taona di Revela u formulisanju italijanske politike na Jadranskom moru 1914-1919. god“, Vojnoistorijski glasnik, 3, 1971, 61-116. 


\title{
МИРОСЛАВ РАДИВОЈЕВИТ \\ Универзитет у Београду, Филозофски факултет \\ Одељење за историју \\ СРБИЈА, УЛАЗАК ИТАЛИЈЕ У ПРВИ СВЕТСКИ РАТ И ЛОНДОНСКИ УГОВОР. НОВО ТУМАЧЕЊЕ
}

\begin{abstract}
Резиме
Преговори Италије са Антантом отпочели су непосредно по избијању Првог светског рата. Иницијативу за придобијање једине преостале државе са статусом велике силе која се налазила ван сукоба, преузео је руски министар иностраних дела, Сергеј Сазонов, помало преурањено, почетком августа 1914. године. У Риму, у том тренутку, још увек нису били спремни да направе тако велики искорак. За италијанску реакцију било је потребно да развој догађаја на фронтовима, у корист једне од две стране, узме довољно значајан обрт. То се десило у фебруару наредне године, са почетком операције француско-британске флоте у Дарданелима. Италија није часила са предлогом да се прикључи Антанти, али су се оствариле зебње руске и српске дипломатије - она је поставила огромне територијалне захтеве на Јадранској обали. Русија је након напорних двомесечних преговора успела да донекле ограничи италијанске претензије и обезбеди довољне компензације за Србију и Црну Гору. Лондонским уговором од 26. априла 1915. српске државе имале су да добију, у перспективи, уз одређен број далматинских острва, простран излаз на море од рта Планка до ушћа реке Дрим, са опцијом да део користе и у војне сврхе. Упркос манипулисању са његовим текстом у југословенској историографији, по увиду и изворни документ, установљено је да су Србији били намењени значајни територијални добици.

Ратне околности у прво време нису утицале на добру сарадњу између ње и Италије. Прве пукотине у пријатељском односу јавиле су се под утицајем пропаганде емиграната Срба, Хрвата и Словенаца из Аустро-Угарске, под егидом владе у Нишу; италијанске окупације Валоне и супротстављање намери да и Србија, из безбедносних разлога, заузме део земљишта немирног суседа, крајем 1914. године. Гласови о тајним преговорима, иза леђа српске владе, покренули су праву лавину. Не обазирући се на осетљивост Италије, српска влада је чинила драматичне представке код држава Тројног споразума, подстицала пропаганду делатност и рад југословенских политичара у иностраној јавности. Несагледавањем шире слике - упорним инсистирањем на „српско-хрватско-словеначком“ уједињењу - вођена тежњом да изазове Италију на ревизију Лондонског уговора у узајамном споразуму, уствари, ушла је у нескривено конфронтирање са њом. На другој страни, ни из Рима нису показивали довољно благонаклоности према интересима малог савезника у Албанији и обазривости у односу са црногорским краљем Николом. На то се надовезао недостатак воље за чињење уступака, ради задобијања добре воље Србије, приликом преговора са неутралним државама. Расцеп у будућности постајао је неизбежан.
\end{abstract}

Кључне речи: Лондонски уговор, Србија, Италија, Русија, Први светски рат, Никола Пашић, Сергеј Сазонов, сер Едвард Греј, југословенско питање, Далмација. 